\title{
PAX-Interacting Protein 1
}

National Cancer Institute

\section{Source}

National Cancer Institute. PAX-Interacting Protein 1. NCI Thesaurus. Code C112904.

PAX-interacting protein 1 (1069 aa, $\sim 121 \mathrm{kDa}$ ) is encoded by the human PAXIP1 gene.

This protein is involved in both DNA damage responses and transcription regulation. 